\title{
INVENTION AND INNOVATION IN ECONOMIC CHANGE
}

\author{
DOI: $10.17261 /$ Pressacademia.2017.450 \\ JEFA-V.4-ISS.2-2017(15)-p.203-208
}

\author{
Sefer Sener ${ }^{1}$, Volkan Hacioglu ${ }^{2}$, Ali Akdemir ${ }^{3}$ \\ ${ }^{1}$ Istanbul University, Faculty of Economics, Istanbul, Turkey. sefersener@istanbul.edu.tr \\ ${ }^{2}$ Istanbul University, Faculty of Economics, Istanbul, Turkey. volkanh@istanbul.edu.tr \\ ${ }^{3}$ istanbul ArelÜniversitesi, Istanbul, Turkey.aliakdemiral@gmail.com
}

To cite this document

Sener, S., V. Hacioglu and A. Akdemir.(2017). Invention and innovation in economic change.Journal of Economics, Finance and Accounting (JEFA), V.4, Iss.2, p.203-208.

Permemant link to this document:http://doi.org/10.17261/Pressacademia.2017.450

Copyright: Published by PressAcademia and limited licenced re-use rights only.

\begin{abstract}
Purpose- In this paper we investigate the difference between invention and innovation. Since theories of invention are rare in the literature, this subject deserves the appropriation of proper attention. In the economics of competitive market, there is an important distinction between invention and innovation.

Methodology- We use qualitative and historical-narrative methodology. An invention is devoid of economic value unless it is put into practical use and consumption. An abstract idea may be an important invention. But it takes an entrepreneur to transform the abstract invention into a marketable product. By "getting things done," the entrepreneur produces economic value and thereby utility.

Findings- The entrepreneur produces utilities by arranging, designing or re-organizing things in a new way that were not done before. On the other hand, the inventor creates ideas to produce something new that was inexistent beforehand.

Conclusion- The task of inventor may seem more essential at first. However, as far as competitive economy is concerned, the function of innovative entrepreneur is determinant in economic change and development. An inventor becomes entrepreneur if endeavor in invention is transformed into labor in entrepreneurship.
\end{abstract}

Keywords:Invention, innovation, economic change, development, entrepreneur.

JEL Codes: 032, 033

\section{INTRODUCTION}

The process of invention and innovation shapes the structure and mechanism of economic change. A clear-cut definition of invention and innovation is only possible by the thorough study of theories that surround those concepts. The origins of invention and innovation also require historical categorization of both terms technically. Many researchers pointed out the difficulties of defining the concept of invention. There are broad and narrow definitions each of which has its own pros and cons.

Besides, social, cultural and psychological aspects of invention and innovation urge multidimensional approaches. In the broadest sense, an invention is an idea that is 'new', 'different' and 'better' as compared to the existing ideas. Indeed, "the term invention can be used to include all human creative activity, from composing a poem to developing a chemical process" Nelson (1959, p. 103). 
This study outlines the process of invention and innovation in terms of economic change from the historical and theoretical perspective. The economic conditions under which inventions are turned from abstract ideas into physical products differ between societies. In every economy there is a social process which produces invention and inventor on the one hand, and innovation and innovator on the other hand.

Plan of the paper is as follows. Section 2 deals with creative action and innovation expectations from the contemporary world view. Section 3 stresses upon the practical distinction between invention and innovation. The theoretical definition of invention and innovation is traced in Section 4. The theories of invention and innovation are analyzed in Section 5. Subsection 5.1 gets into the details of Usher's Theory of Strategic Invention. In Subsection 5.2, a comparison is made between Usher and Schumpeter on invention and innovation. Section 6 concludes with remarks on the relevant literature.

\section{CREATIVE ACTION AND INNOVATION EXPECTATIONS}

The modus operandi of economic life is not designed as mechanical as a machinery process. It changes with the wind of animal spirits. Sunspot expectations are in play more than ever as a self-fulfilling prophecy or what Popper (1957) called it as 'Oedipus Effect' of modern times. Innovation expectations are also a kind of sunspot expectations as an extrinsic random variable that affects the fluctuations out of economic fundamentals. The trend of globalization is also a source of destabilization. We are living in a more uncertain world than ever before. Every novelty comes with new opportunities and challenges.

People in our age are more aware of psychological factors that drive them to consume, save and invest if possible. They don't behave as if their propensity to consume increase or decrease along their consumption function. They don't enter into the labor market to sell their labor in quantity units. They don't make accurate calculations and dive into cost considerations to maximize their expected utilities.

If rationality is one of the determinant factors of productivity, irrationality is also a determinant factor of creativity. Most of the innovations come after emotional creative spurts and most individuals believe that they work better with creative spurts than routine periods of employment. Without the element of creativity, marginal productivity will gradually decrease in time and eventually cease to exist or be on a very low level in the long run. The element of creativity always comes with the entrepreneurial spirit. This is so in all arts and sciences. In order to investigate the nature of creativity as an element of innovation that causes economic development and change, we need to understand the concept of entrepreneurship.

The entrepreneur is he who invents new ways of doing things to open new vistas for efficient production. As Schumpeter states "a study of creative response in business becomes coterminous with a study of entrepreneurship. The mechanisms of economic change in capitalist society pivot on entrepreneurial activity" (Schumpeter, 1947, p. 150). Of course the entrepreneurial activity is not restricted to the capitalist society. But Schumpeter singles out capitalist entrepreneurship as a sufficiently distinct phenomenon that is at the heart of economic change.

\section{THE DISTINCTION BETWEEN INVENTION AND INNOVATION}

In a capitalist society, there is an important distinction between invention and innovation. An invention is devoid of economic value unless it is put into practical use and consumption. An abstract idea may be an important invention. But it takes an entrepreneur to transform the abstract invention into a marketable product. By "getting things done," the entrepreneur produces economic value and thereby utility.

The inventor and the entrepreneur may or may not be the same person. Telephone was invented by Graham Bell. At the outset, Bell was trying to help people whose hearings are impaired, and one of them was his mother. This was not at all an economic motive. Bell was an outright inventor. Today telephones are evolved into a technological miracle. As a capitalist entrepreneur, Steve Jobs' handy design of iPhones was an absolute innovation which added considerable amount of economic value to the original invention. It created great amount of marketable value and utility by revolutionizing the uses and functions of telephone in many ways. Perfect competition renders perfect price and profit opportunities.

An invention may remain dormant for years until an entrepreneur comes up with an innovation that is apt to mass production. When inventions are properly adopted in the production process, they become innovations for they contribute to the productivity of resources (Rosenberg, 1974). Innovation adoption capacity of entrepreneurs closely related with the diffusion process of new ideas in the society. Schmookler (1966) deals with inventive activity in economic terms. Since he considers demand-side economics, Schmookler (1966) does not make any difference and clarification between invention and innovation. As far as the economic consequences of inventive activity are concerned, the difference between invention and innovation is important. 
If 'marketableness' is the keyword for an innovative product to become successful, then 'profitableness' is another root that always comes under the former. Profit opportunity in a business enterprise attracts the attention and drives the labor of capitalist entrepreneur whereas an inventor may be moved by the motives other than profit seeking as in the case of Bell. This entrepreneurial instinct inspected as the psychology of making money versus the altruistic instinct of devotion to contrivance by Taussing (1915).

\section{THE THEORETICAL DEFINITIONS OF INVENTION AND INNOVATION}

The theoretical definitions of invention and innovation require getting into the details of modus operandi in the ordinary course of economic life. One of the broad definitions of invention can be found in Schumpeter's concept of creative response. According to this approach, a change in the "mechanisms" of getting things done in a better and more efficient way that is different from the manner that has hitherto been done can be thought as invention (Schumpeter, 1947).

The very early form of creative response falls into the general category of invention. Schumpeter (1947) classifies three important properties for creative economic activity. The first point is of unpredictability. This quality of creative activity makes the difference between ex-ante and ex-post in the event of invention. From the standpoint of the observer, an invention is almost always out of perfect foresight. This corresponds contradictorily to the hypothesis of rational expectations. So how and under which historical and social conditions an invention happens are crucial questions to be investigated in the field of economic science.

Second property is concerned with the very nature of creative action and reaction. Creative action operates through creative destruction which is another Schumpeterian concept. Creative response changes the existing social and economic structures, infrastructures and superstructures sometimes with a single strike and sometimes with waves of subsequent strikes. The impact of creative response has its full effect upon the secular growth trend in the economy. Creative action causes a sea-change in the economy and this is different from which economists tend to call "transitions." For this reason, creative response is an historical process as opposed to a strict theoretical setting in which the final outcome is determined by the initial data (Schumpeter, 1947).

Third property is related with the quality of human capital in a society. Since the human quality in a certain society at a particular time is homogeneous, it is important to distinguish relative qualities in different field of activity. The human quality required in the agricultural sector will be well different from that of high-tech industries. Sophistication and education of personnel among the layers of society provide qualified entrepreneurial power for economic change.

When we move from the broad definition of invention to a more specific one, we arrive at an approach that puts innovation on the basis of cultural change: "any thought, behavior, or thing that is new because it is qualitatively different from existing forms. Strictly speaking, every invention is an idea, or constellation of ideas; but some inventions by their nature must remain mental organizations only, whereas others may be given overt and tangible expression" (Barnett, 1953, p. 7).

From this definition, another classification arises. Every invention is born out of an abstract idea in human mind. And some of them are realized in a concrete form. Hence an inventor is not necessarily an entrepreneur. There is a difference between creating a new idea and "getting things done." Economical organization and arrangement of material things to produce utility are far beyond to create a novel idea. Schumpeter (1947) gives some examples of this distinction. For instance, although Greek science had all that is necessary to build a steam engine, the imagination of Greek people did not create a steam engine in antiquity. This shows that the material progress of the society is cumulative and comprehensive.

The order of concepts follows the natural course: imitation precedes invention (imitation of flight of birds preceded the invention of the plane), invention precedes innovation (invention of the plane preceded the innovations in aircraft industry), and innovation precedes implementation. Every phase requires specific cultural and economic conditions. In some cultures, inventions precede innovations with a long lag or inventions exist without innovations. In China, printing press was invented but never implemented at a large scale. Likewise, in Egypt papyrus was invented but it was not manufactured as a mass production. However, when cause and effect connection is considered, inventions always come before innovations and the former is seen as a requisite precondition for the latter (Baumol, 2002, pp. 9-10). Another definition of invention and innovation takes the above practical difference in consideration. From this perspective, the innovation is defined as "the production of new technical knowledge" (Elster, 1983, p. 93). Accordingly, the invention is defined as an activity for "the generation of some scientific idea, theory or concept that may lead to an innovation when applied to a process of production" (Elster, 1983, p. 93).

\section{THE THEORIES OF INVENTION AND INNOVATION}

Theories of invention and innovation can be grouped into three categories. In the first category, neo-classical theories of growth take place. In this framework, invention and innovation are embedded in the term of technology. Technology is integrated into the growth models of production. But the role of entrepreneur is rather blurred in this context. When we 
recall from Schumpeter that the invention and innovation are mere entrepreneurial activities, it is hard to exaggerate the role of entrepreneur in economic growth.

In the second category, there is Schumpeterian Theory of Entrepreneur. According to Schumpeter (1912) technological change has three phases each of which creates conditions sufficient for economic development:

(i.) Invention as a creation of new ideas which are systematically turned into technologies;

(ii.) Innovation as commercialization of invented ideas into marketable forms of production;

(iii.)Diffusion as disseminating new ways of "getting things done" through the different layers of production.

In the third category, the theory of evolutionary economy sets up. In evolutionary conception, the invention is seen as a process rather than a separate occasion. In this respect, "the transcendentalist approach, which attributes the emergence of invention to the inspiration of the occasional genius who from time to time achieves a direct knowledge of essential truth through the exercise of intuition, is rejected as unhistorical" (Ruttan, 1959, p. 600). Schumpeterian theory of entrepreneur is developed into the theory of invention by early American writers such as Ogburn (1922), Usher (1929), Kaempffert (1930) and Gilfillan (1935). This was a reaction chiefly to the Great Man Theory of Transcendentalism (Arthur, 2007, p. 247)

\subsection{Usher's Theory of Strategic Invention: The Cumulative Synthesis Approach}

Abbott Payson Usher's (1929) Theory of Strategic Invention is based upon Gestalt experiments of Wolfgang Köhler (1926). It is a rejection of both the transcendentalist and the mechanistic theories of invention. Usher formulates the cumulative synthesis approach as an alternative to the transcendentalist and mechanistic process theories of invention (Ruttan, 1959). According to Usher's Theory of Strategic Invention, a kind of Keynesian animal spirit is at play. Inventive activity under amenable conditions flourishes as an act of insight:

"Acts of skill include all learned activities whether the process of learning is an achievement of an isolated adult individual or a response to instructions by other individuals. Inventive acts of insight are unlearned activities that result in new organizations of prior knowledge and experience..." (Usher, p .526).

This act of individual insight is carried out in four moves as follows:

(i.) Perception of the Problem.-The first move is the drive to act upon the perception of a problem. The problem is perceived because it creates distress as incompleteness or dissatisfaction for the fullness of life. The true nature of the problem is of a desire that is not fulfilled.

(ii.) Setting the Stage.-The second move is the setting of the stage which depends upon pure chance. At this move, the individual acts upon haphazard happening of events or wayward thoughts. The individual learns from trial and error experiment and the shadow teaches the wanderer its lesson. The individual as an 'economic actor' collects the elements, material things and knowledge, and manipulate them with its skill to find solution.

(iii.) The Act of Insight.-The third move is the acting out of the configurations for which the individual prepared during the setting of the stage. By this move, the individual verifies that it found a solution to the problem. Here the element of uncertainty enters into the scene. The uncertainties of the environment-vicissitudes of particular time and particular place-are the most important factors that affect the outcome.

(iv.) Critical Revision.-The fourth and final move is time for the individual to critically revise its course of action during previous moves. The individual makes sure that the solution is practical in its detail and can be used as a technique at a later date. The old adage holds at this step: practice makes perfect!

Usher's Theory of Strategic Invention concentrates on the cumulative synthesis of collective individual inventions which are observed frequently in the ordinary business of life. "Such acts of insight frequently emerge in the course of performing acts of skill, though characteristically the act of insight is induced by the conscious perception of an unsatisfactory gap in knowledge or mode of action" (Usher, 1955, p. 523).

\subsection{Usher and Schumpeter on Invention and Innovation}

Ruttan (1959) attempts to clarify the meaning of the concepts of invention and innovation with a comparison of Schumpeter's theory of innovative entrepreneurship in the process of economic development to Usher's theory on the emergence of strategic inventions. Goddin (2008) discusses in detail the theories on invention and innovation in a Project on the Intellectual History of Innovation. Schumpeter (1912), by borrowing from Ricardo, theoretically classifies innovation in five categories:

(i.) Introduction of new products by which "new utilities" come into existence.

(ii.) Finding new ways - techniques and methods-of production for existing products.

(iii.) Opening up of new markets or networks of markets. 
(iv.) Discovery of new sources of supplies. Implementation of new forms of industrial and institutional organization that will improve efficiency in production.

In this classification, 'invention' and 'discovery' are used synonymously. According to Schumpeter "innovation is possible without anything we should identify as invention and invention does not necessarily induce innovation, but produce of itself no economically relevant effect at all" (Schumpeter, 1939, p. 84).

The theoretical distinction between invention and innovation made by Schumpeter is criticized as artificial (Solo, 1951). It was difficult to maintain such a distinction which explains the relation between inventors, innovators and entrepreneurs as "merely a change of coincidence" (Ruttan, 1959). The relation between inventors, innovators and entrepreneurs are systematically analyzed as an industrial process (Maclaurin, 1950).

The advantage of the Usher's theory is its focus on conscious and deliberate efforts - rather than transcendentalist approach of obscure occasions which are subconscious by their very nature-to control the speed and direction of inventions and innovations. The process of cumulative synthesis comprises individual elements of novelty that cluster around the new synthesis. The control factor of cumulative process concentrates in setting the stage and critical revision steps. The individual sets the stage in a manner that the element of chance is minimized though not eliminated outright. Also, Usher's theory overcomes the difficulty in the artificial distinction between the process of invention and the process of innovation in Schumpeterian approach.

\section{CONCLUDING REMARKS}

Every new era requires its own novelty. Inventions and innovations also evolve over time and they are subject to change. The distinction between invention and innovation ranges from one field to another. The creative process spans over wide area of knowledge. There is an increasing attention on the invention and innovation in economics. The importance of human factor as an innovative entrepreneur makes its way out of standard definitions of rational producers and consumers that are sketched in economic mind.

The process of invention and innovation is one of the most complicated subjects in the fields of economic science. For this reason, in modeling innovative human behavior, both theoretical and historical perspectives are needed. Schumpeter introduced the innovative entrepreneur into the theory of economic development. The most decisive difference between invention and innovation is economical. An invention of abstract idea has no economical value. Inventions in mathematics are examples for these kinds of discoveries. The abstract idea needs to be turned into a physical product that produces utilities and thereby satisfies human wants. A marketable new product includes innovation as a value added.

The historical course of events follows natural evolutions. Thereby the order of economic change begins with imitation, and then comes invention, and subsequently innovation. Schumpeter defines invention as a creative response. There are three important properties of creative response in a socio-economic condition. First is the unpredictability of inventive activity. Inventions cannot be forecasted by deterministic ways of empiricism. Second, inventions are part of creative destruction. Third property concerns with the quality of human capital in a society.

In neo-classical theories of growth, technology was exogenous. The entrepreneur was absent and the process of invention and innovation was a black box. Endogenous growth models integrated the element of technology into the neo-classical models. But they did not shed light on the dark and deep realms of innovative entrepreneurship. Schumpeterian theory of entrepreneur opened the black box. However, Schumpeter's conception of innovative entrepreneur was not a theory of invention and innovation. Even today, theories of invention are relatively scarce in literature.

Usher's Theory of Strategic Invention developed a cumulative synthesis approach. It was a rejection of both transcendentalist and mechanistic process theories of invention. This theory is an inquiry into the individual inventive acts of insight. According to Usher, social process of invention and innovation consists of acts of insight. This analysis focuses on the insights into individual mental and social processes provided by Gestalt psychology. Novelty emerges in the individual act of insight on four steps which is a synthesis of familiar items: (1) perception of problem or an incomplete pattern in Gestalt terminology; (2) the setting of the stage on which the individual act of insight is formed or configured; (3) the performance of the act of insight; (4) critical revision to master the new pattern.

In order to understand the mechanism of economic development, economists should work interdisciplinary. History and sociology provide ample experiments than those in isolated laboratories with unrealistic assumptions. The innovative entrepreneur was an elf bottled out by Schumpeter. Now it is time to investigate the potential powers of this intangible engine to conduct it more efficiently and effectively than ever before. Because the power without control is of no avail. 


\section{REFERENCES}

Arthur, W. B. (2007). "The Structure of Invention," Research Policy, Vol. 36, pp. 274-287.

Barnett, H. G. (1953). Innovation: The Basis of Cultural Change, New York: McGraw-Hill.

Baumol, W. J. (2002). The Free-Market Innovation Machine: Analyzing the Growth Miracle of Capitalism, New Jersey: Princeton University Press.

Elster, J. (1983). Explaining Technical Change: A Case Study in the Philosophy of Science, Cambridge: Cambridge University Press.

Gilfillan, S. C. (1935). The Sociology of Invention, Cambridge: Follett.

Goddin, B. (2008). "Innovation: the History of a Category," Project on the Intellectual History of Innovation, Working Paper No. 1.

Kaempffert, W. (1930).Invention and Society, Chicago: American Library Association.

Köhler, W. (1926).The Mentality of Apes, London: Harcourt, Brace.

Maclaurin, W. R. (1950). "The Process of Technological Innovation: The Launching of a New Scientific Industry,"American Economic Review, Vol. 60, pp. 90-112.

Nelson, R. R. (1959). "The Economics of Invention: A Survey of the Literature," The Journal of Business, Vol. 32, pp. $101-127$.

Ogburn, W. F. (1922). Social Change with Respect to Culture and Original Nature, New York: B. W. Huebsch, Inc.

Rosenberg, N. (1974). "Science, Invention and Economic Growth," The Economic Journal, Vol. 84, No. 333, pp. 90-108.

Ruttan, V. W. (1959). "Usher and Schumpeter on Invention, Innovation, and Technological Change," The Quarterly Journal of Economics, Vol. 73(4), pp. 596-606.

Schumpeter, J.A. (1939).Business Cycles: A Theoretical, Historical, and Statistical Analysis of the Capitalist Process, New York: McGraw-Hill.

Schumpeter, J. A. (1947). "The Creative Response in Economic History,"The Journal of Economic History, Vol. 7, No. 2, pp. 149-159.

Schumpeter, J.A. (1912), The Theory of Economic Development: An Inquiry into Profits, Capital, Credit, Interest, and the Business Cycle, Cambridge: Harvard University Press.

Schmookler, J. (1966). Invention and Economic Growth, Cambridge: Harvard University Press.

Solo, C. S. (1951). "Innovation in the Capitalist Process: A Critique of the Schumpeterian Theory," The Quarterly Journal of Economics, Vol. 65, pp. 417-28.

Taussing, F. W. (1915). Inventors and Money-Makers. New York: The Macmillan Company

Usher, A. P. (1929). A History of Mechanical Inventions, New York: Dover.

Usher, A. P. (1955). "Technical Change and Capital Formation” in Capital Formation and Economic Growth, National Bureau Committee for Economic Research, Princeton: Princeton University Press. 